\title{
Justiça juvenil no Brasil
}

\section{Continuidades e rupturas}

\author{
Ana Claudia Cifali* \\ https://orcid.org/0000-0002-7771-9465 \\ Mariana Chies-Santos* * \\ https://orcid.org/0000-0002-8151-9044 \\ Marcos César Alvarez* * \\ https://orcid.org/0000-0001-5984-9082
}

Castigos... Castigo... É a palavra que Pedro Bala mais ouve no reformatório. Por qualquer coisa são espancados, por um nada são castigados. O ódio se acumula dentro de todos eles. Jorge Amado, Capitães da areia.

Introdução

No Brasil, para grande parte de pesquisadores, militantes e operadores envolvidos com a questão dos jovens em conflito com a lei, o Estatuto da Criança e do Adolescente, de 1990, foi um importante marco na afirmação e defesa dos direitos da infância e da juventude no país, em oposição às anteriores leis e práticas organizadas em torno dos Códigos de Menores (1927, 1979). No entanto, constata-se igualmente que a mudança da norma jurídica parece não ter sido suficiente para, em diversos aspectos, alterar as práticas seletivas e estigmatizadoras da justiça juvenil no país. Pesquisas no âmbito da Sociologia, ao observarem o funcionamento dessa justiça e das instituiçôes de internação ou de aplicação de medidas socioeducativas, costumam indicar tal paradoxo. Quer na observação do perfil sociodemográfico

* Instituto Alana, São Paulo, Brasil.

** Universidade de São Paulo, São Paulo, Brasil. 
dos adolescentes em conflito com a lei, quer da frouxa articulação dos órgãos que compõem a justiça juvenil, quer do aspecto de "linha de montagem" das decisões tomadas pelos operadores, o quadro permanece marcado pela seletividade na aplicação das medidas de internação e socioeducativas, por formas de classificação que opõem adolescentes considerados recuperáveis aos não recuperáveis, perigosos e não perigosos, pelo avanço do punitivismo, enfim, por um amplo processo de sujeição criminal de setores da população, jovens do sexo masculino, negros e com baixa renda e escolaridade (Gonçalves, 2020).

Neste texto, a partir de pesquisas já realizadas (Alvarez, 1989, 2003; Chies-Santos, 2018; Cifali, 2019), do diálogo crítico com parte ${ }^{1}$ da produção existente sobre o tema no âmbito da Sociologia e da Criminologia no país e com abordagens que problematizam os efeitos mais amplos, em termos de formas de controle social, bem como da Justiça Juvenil na literatura internacional (Foucault, 1977; Donzelot, 1980; Platt, 1982, Sallée, 2016, entre muitos outros), busca-se refletir acerca das possíveis continuidades e rupturas, ao longo da história brasileira, dessa justiça no país. Dos Códigos de Menores de 1927 e 1979 ao ECA, passando pela criação do Serviço de Assistência aos Menores, da Funabem etc., operadores do direito, setores das elites políticas, especialistas e pesquisadores, movimentos sociais, imprensa e outros atores redesenharam permanentemente essa área de atuação estatal, ao mobilizarem saberes e diagnósticos diversos. Busca-se recuperar a complexidade de tal trajetória histórica para melhor refletir acerca dos paradoxos da justiça juvenil ainda na atualidade.

\section{A emergência do Código de Menores de 1927}

No que diz respeito ao desenvolvimento dos direitos infantojuvenis no Brasil, assim como no que diz respeito a outras dimensões legais e institucionais, o país acompanhou, sem dúvida, movimentos que já ocorriam em âmbito internacional. Emilio García Méndez, por exemplo, caracteriza que o tema de responsabilidade penal da criança e do adolescente transitou por três grandes etapas na América Latina: (i) do século XIX até 1919 e que vinha desde os Códigos Penais da Corte, possuía características meramente retribucionistas; assim, "essa etapa considera[va] os menores de idade praticamente igua[is] aos adultos, com exceção aos menores de sete anos" (Méndez, 2000, p. 9); (ii) a segunda etapa tinha caráter meramente tutelar e, nesse sentido, é de se considerar que a América Latina tinha influência de um movimento

1. É vasta a produção a respeito do tema no Brasil, mesmo considerando-se apenas o âmbito dos estudos sociológicos e criminológicos, o que impõe a necessidade de selecionar trabalhos e abordagens aqui considerados significativos para a presente discussão. Para uma revisão dos trabalhos da Sociologia centrados apenas na atuação dos agentes judiciais no sistema de justiça juvenil, conferir Gonçalves (2020). 
reformista que havia se iniciado nos Estados Unidos (EUA) e passado pela Europa, que exigia "no sólo una legislación especializada (las leyes de menores), sino también una administración especializada de la cuestión minoril (los Tribunales de Menores)" (Méndez, 2000, p. 9). Assim, em 1919, a Argentina fez a primeira reforma inspirada nessas ideias (Ley Agote), que só viria a se consolidar no Brasil em 1927; (iii) a terceira etapa inicia-se em 1989, com a aprovação da Convenção Internacional dos Direitos da Criança, das Nações Unidas. A partir dessa etapa, crianças e adolescentes passariam a ser reconhecidos como sujeitos de direitos.

Esse tipo de periodização, no entanto, perde de vista as específicas configurações locais, tanto em termos legais quanto institucionais, nos diferentes países, bem como assume uma visão progressista que torna difícil a compreensão dos avanços, recuos e permanências dos aspectos seletivos e estigmatizadores já relatados.

Especificamente no Brasil, a questão de uma legislação específica para crianças e adolescentes no país começa a ganhar força com a Abolição (1888), a mudança do regime político (1889) e a subsequente promulgação do Código Penal da República de 1890 (Brasil, 1890). No âmbito da produção doutrinária, o jurista Tobias Barreto é um pioneiro nessas discussões no país. Em livro publicado pela primeira vez em 1884, intitulado Menores e loucos, Barreto fazia a crítica ao critério do "discernimento", presente no Código Criminal do Império. De acordo com esse dispositivo, os menores de catorze anos não seriam julgados criminosos, salvo se tivessem agido com discernimento. Barreto argumentava que seria uma temeridade considerar, diante das precárias condições de vida no Brasil, a possibilidade de responsabilização penal dos menores (Barreto, 1926). Embora o Código Penal de 1890 não tenha rompido com o critério do "discernimento", abria-se na discussão doutrinária a possibilidade da defesa de uma legislação específica para esses "menores" que prosseguirá ao longo das primeiras décadas do século $\mathrm{xx}$.

Beatriz Sofia Mineiro, advogada atuante junto ao Juízo de Menores do Rio de Janeiro, na segunda década do século $\mathrm{xx}$, ao resumir as iniciativas legais de criação de uma legislação de "proteção e assistência à infância" junto ao Congresso Nacional, aponta como pioneiro o projeto encaminhado por Lopes Trovão, em 1902, seguindo-se, entre outras, as iniciativas de Alcindo Guanabara, em 1906 e 1917, e as iniciativas posteriores do juiz Mello Mattos, primeiro Juiz de Menores do Brasil, nomeado em 1924, que será o nome emblemático em torno da aprovação do primeiro Código de Menores no país (Mineiro, 1929).

Como afirmado, entretanto, a construção social do "menor" não será um processo linear, organizado exclusivamente pelos juristas da época. Um discurso que irá apresentar crianças e adolescentes nas ruas dos grandes centros urbanos como figuras da desordem aparecerá em diversos momentos, tanto nos discursos políticos, 
quanto igualmente na imprensa. O advogado e político Paulo Egídio de Oliveira Carvalho (1842-1906), por exemplo, em seus discursos no Senado em São Paulo, num contexto de acelerado processo de urbanização da cidade, de imigração e de não incorporação de grande número de pessoas ao novo mundo do trabalho assalariado, apresentará os menores nas ruas como algo digno de preocupação:

Vemos pelas ruas mais centrais da cidade inúmeras crianças vagando à toa, mendigando aos transeuntes, crianças, aliás, dotadas de robustez física, indicada por sinais que revelam uma boa constituição psicológica, mas que, entretanto, colocadas em um meio deletério, habituadas à vida minguada da terra donde partiram, acreditando que neste país a vida absolutamente nada custa, vivem à toa, à procura de seu destino, como se neste como em todos os países fosse possível a conquista da vida por outra lei que não a lei do trabalho (São Paulo, 1893, apud Alvarez, 2003, p. 64).

Paulo Egídio, consequentemente, defenderá, como parte de sua reforma penitenciária, a necessidade de criação de um "Asilo Industrial” destinado a recolher crianças de ambos os sexos que mendigassem pela cidade, que tivessem pais condenados por sentença criminal ou em cumprimento de pena, órfãos ou abandonados. Tal proposta não terá continuidade, mas Egídio apoiará o projeto de outro jurista da época, Cândido Mota, para a criação de um Instituto Disciplinar em São Paulo, em 1902. Assim, mesmo que um Código específico para os "menores" ainda demorasse a surgir, mudanças já em curso no início do século permitiam novas formas de institucionalização da infância e da adolescência consideradas em situação de abandono e precocemente voltadas à delinquência.

A atuação e os projetos de Paulo Egídio e de Cândido Motta indicam igualmente como, ao longo de toda a Primeira República, as ideias da assim chamada Escola Italiana de Criminologia ou Nova Escola Penal desempenharam um papel significativo na construção de um discurso coerente sobre os menores como alvos de ações estatais (Alvarez, 2003) ${ }^{2}$, bem como na legitimação de instituições de internação especializadas que começavam a ser criadas no país. Cesare Lombroso, a figura mítica dessa escola, justamente alertava para a infância como momento decisivo no qual se manifestariam as sementes da loucura e do crime (Lombroso, 1887).

Formas de rotulação e de estigmatização da infância pobre, sobretudo nos grandes centros urbanos em acelerado crescimento na época, também emergiam, sem dúvida, no cotidiano das práticas policiais. Boris Fausto (1984), ao estudar a criminalidade em São Paulo no início do século xx, mostra como a atividade policial, na época, 
visava não apenas ao controle da criminalidade, mas igualmente a um controle social mais amplo em relação a determinados setores da população, alcançando também os "menores". Adriana Vianna (1999), por sua vez, ao investigar o processo de construção do "menor" como personagem social nas duas primeiras décadas do século xx no Rio de Janeiro, enfatiza igualmente o papel da atividade policial cotidiana e seus esquemas classificatórios - abandonados, vadios incorrigíveis, reincidentes etc. - na construção desses sujeitos socialmente subordinados. A polícia, assim, não teria sido um agente periférico, mas fundamental na instituição das representações sobre o menor e a menoridade.

Não é possível negar, no entanto, a atuação paralela de diversos setores das elites no período para a paulatina construção de uma política específica para equacionar os problemas da proteção e da punição desse grupo social, transformado em figura da desordem. A subsequente judicialização da questão da menoridade, com a criação, em 1923, do juízo de menores no Rio de Janeiro, e a atuação do Juiz Mello Mattos abriram caminho definitivo para a posterior promulgação do primeiro Código de Menores do país, em 1927, apoiada por juristas, médicos, filantropos, higienistas, empresários etc. (Alvarez, 1989; Braga, 1993; Vianna, 1999).

O Código de Menores de 1927 forneceu os contornos de uma nova justiça especial que deslocava o eixo da tutela em relação aos menores da família em direção ao Estado. Igualmente, todo um discurso que articulava as questões do abandono e da delinquência precoce, da assistência e da justiça simultaneamente, se estabilizava, ao desenhar um dispositivo (Foucault, 1980) de governo de crianças e de adolescentes pobres. O “menor", a partir de então, será aquele que se inscreverá privilegiadamente nas relações entre abandono e delinquência (Alvarez, 1989). Como se verá a seguir, desdobramentos e reformas diversas irão ocorrer nas décadas seguintes, mas sem romper com esse novo marco legal e institucional. Da mesma forma, a figura do menor seguirá impregnando o imaginário social do país, ao permear decisões judiciais, projetos de alteraçôes legislativas e práticas policiais e institucionais.

\section{Do Serviço de Assistência aos Menores à Política Nacional de Bem-Estar do Menor}

Tomando como base o período de 1923 a 1941, ou seja, da criação do juizado de menores à instituição do Serviço de Assistência aos Menores (SAM), Rizzini (1993) analisa as concepções dicotômicas de "menor" e de "criança" que se aprofundaram especialmente na prática jurídica no referido período. A autora ainda destaca que a grande influência dos saberes considerados científicos sobre a prática jurídica serviu para justificar a privação de liberdade daqueles inseridos na categoria "menor", ao reforçar práticas discriminatórias e excludentes. 
O Código Penal de 1940, em sua exposição de motivos, declarava que: "não cuida o projeto dos imaturos (menores de dezoito anos) senão para declará-los inteira e irrestritamente fora do direito penal, sujeitos apenas à pedagogia corretiva da legislação especial”. Tal legislação especial dizia respeito justamente ao já citado Código de Menores de 1927 (Brasil, 1940). Nesse momento, portanto, o poder legislativo optou por manter a intervenção estatal sobre os menores de dezoito anos em um âmbito supostamente especializado. Em seguida, em 1942, foi criado o citado SAM, órgão que atuaria como um equivalente ao sistema penitenciário, mas direcionado especialmente à população adolescente, o que ocorreu em razão do aumento da população juvenil institucionalizada (Saraiva, 2005; Rizzini, 2007).

O sAm tinha como missão, por exemplo, resguardar os menores carentes, abandonados e infratores e, para isso, centralizava a execução de uma política nacional de atendimento. Executava, portanto, as medidas aplicadas pelos Juízes de Menores, com um caráter corretivo-repressivo assistencial em todo o território nacional. Faleiros aponta que:

\begin{abstract}
A implantação do SAM tem mais a ver com a questão da ordem social que da assistência propriamente dita. [...] Vinculada ao Ministério da Justiça e do juizado de menores, tem como competência orientar e fiscalizar educandários particulares, investigar os menores para fins de internação e ajustamento social, proceder ao exame médico-psicopedagógico, abrigar e distribuir os menores pelos estabelecimentos, promover a colocação dos menores, incentivar a iniciativa particular de assistência a menores e estudar as causas do abandono (Faleiros, 2009, p. 55).
\end{abstract}

Dessa forma, permanecia o modelo que associava abandono e delinquência. Apesar da criação de um serviço estatal mais amplo voltado para crianças e adolescentes, reproduzia-se a visão de que os "menores" deveriam ser igualmente objeto de favor e de caridade por parte das instituições de cunho religioso e filantrópicas (Paula, 2004). Earp (1993) destaca que esse modelo também tinha como objetivo a criação de "indivíduos úteis". Dentro das instituições do SAM, crianças e adolescentes seriam supostamente profissionalizados para que pudessem trabalhar e, por conseguinte, adquirir o estatuto de cidadãos. Porém, ao longo do tempo, o SAM passou a ser duramente criticado por ex-diretores, políticos e juristas, tanto pelas práticas de violência, quanto pela precariedade de suas instalações.

Assim, ao longo do tempo, junto às críticas à violência praticada contra os jovens no interior do SAM, o Código de Menores passou a ser alvo de questionamentos, mas as consequências do golpe militar de 1964 serviram como obstáculos aos movimentos que já demandavam mudanças na perspectiva adotada pela legislação menorista 
(Oliveira, 2005). Como resposta a essas críticas, por meio da Lei n. 4.513 de 1964, estabeleceu-se a Política Nacional de Bem-Estar do Menor (PNBEM), criando-se "uma gestão centralizadora e vertical, baseada em padrões uniformes de atenção direta implementados por órgãos executores inteiramente uniformes em termos de conteúdo, método e gestão" (Saraiva, 2005, p. 47). O órgão nacional gestor dessa política passou a ser a Funabem (Fundação Nacional do Bem-Estar do Menor) e, no âmbito estadual, as Febems (Fundação Estadual do Bem-Estar do Menor).

A atuação da Funabem organizava-se, ao menos oficialmente, em torno de dois eixos básicos: a correção e a prevenção das chamadas "causas do desajustamento do menor”. Tratava-se de diagnosticar para, então, tratar comportamentos “anormais", sintomas ou expressões de desequilíbrios e doenças. Os conceitos mais utilizados no período são "marginalidade" e "periculosidade", elementos jurídicos, mas que ganhavam tons de cientificidade ao se determinar que deveriam ser avaliados por técnicos. A partir da avaliação de periculosidade o adolescente seria liberado, desde que verificada a "cessação da periculosidade" ${ }^{3}$. Nesse sentido, vale trazer trecho da lei em que isso é, de certa forma, explicado:

Art. $2^{\circ}$ : São as seguintes as medidas aplicáveis aos menores de 14 a 18 anos:

I - se os motivos e as circunstâncias do fato e as condições do menor não evidenciam periculosidade, o Juiz poderá deixá-lo com o pai ou responsável, confiá-lo a tutor ou a quem assuma a sua guarda, ou mandar interná-lo em estabelecimento de reeducação ou profissional e, a qualquer tempo, revogar ou modificar a decisão;

II - se os elementos referidos no item anterior evidenciam periculosidade, o menor será internado em estabelecimento adequado, até que, mediante parecer do respectivo diretor ou do órgão administrativo competente e do Ministério Público, o Juiz declare a cessação da periculosidade.

$\$ 1^{\circ}$ Completada a maioridade sem que haja sido declarada a cessação da periculosidade, observar-se-ão os $\$ \$ 2^{\circ}$ e $3^{\circ}$ do art. $7^{\circ}$ do Decreto-lei número 3.914, de 9 de dezembro de 1941. $\$ 2^{\circ} \mathrm{O}$ Juiz poderá sujeitar o menor desligado em virtude de cessação de periculosidade à vigilância, nas condições e pelo prazo que fixar, e cassar o desligamento no caso de inobservância das condições, ou de nova revelação de periculosidade (Brasil, 1968).

3. O Decreto-Lei n. 6.026, de 1943, era a legislação a dispor sobre as medidas aplicadas aos menores de dezoito anos pela prática de infrações penais. É nesse decreto que fica explícito, por exemplo, como se daria a cessação da periculosidade daquele menor. De acordo com a norma, se os motivos e as circunstâncias do fato e as condições do menor evidenciassem periculosidade, ele seria internado em estabelecimento adequado, até que, mediante parecer do respectivo diretor ou do órgão administrativo competente e do Ministério Público, o Juiz declarasse a cessação da periculosidade. 
A percepção era de que "o mal estaria localizado no indivíduo, geralmente definido como fenômeno endógeno ou mesmo hereditário", percepção que, segundo Earp (1993, p. 76), passava a ser veiculada como uma ideologia do governo, que desenvolveu uma metodologia, um vocabulário e um sistema de classificação vistos como científicos, e, além disso, contava com extraordinários recursos para Relações Públicas e Desenvolvimento de Pessoal. Nesse sentido, a Revista Brasil Jovem, publicada pela Funabem, era tida como um repositório da "ciência menorista", e o aporte conceitual e teórico dava conta de que "a sociedade é boa, o homem (ou a criança) marginal é que está doente" (Earp, 1993, p. 78). Com a revista da Funabem, passa-se a coordenar a disseminação de um "saber oficial” centralizado, sistematizado e considerado científico sobre o chamado "problema dos menores".

De acordo com Cavalieri (1986), o clima estabelecido pela Funabem propiciou a fundação da Associação Brasileira dos Juízes de Menores, o restabelecimento dos Congressos de Juízes de Menores, além da implantação da matéria direito do menor nas Faculdades de Direito e o aparecimento de uma literatura especializada, com a multiplicação de simpósios, seminários e congressos, criação de novos juizados especializados e a valorização dos técnicos e demais atores do sistema de justiça. Destaca-se, além disso, uma vinculação dos juízes de menores ao modelo de intervenção positivado pelo Código de Menores e à visão cientificista, articulada aos saberes "psi”.

Becher (2011), ao tratar sobre o tema, verificou as relações teóricas e práticas entre o sistema de justiça juvenil instituído pela PNBEM e a Doutrina da Segurança Nacional, especialmente no que se refere à estratégia psicossocial de coerção e controle da população. Passetti (1991) também apontou relações entre a política de intervenção sobre a juventude, desenvolvida no período militar, e a política geral de desenvolvimento executada pela Escola Superior de Guerra. Ainda, Becher (2011) verificou que a criação da Funabem era recorrentemente reivindicada como um produto do "processo revolucionário" de 1964, vinculando-se aos objetivos civil-militares de construção do "homem do amanhã". Nesse sentido, de acordo com Mário Altenfelder, então médico e presidente da Funabem:

\footnotetext{
E foi uma vitória da Revolução de 31 de Março. Não fosse essa Revolução, acredito que nunca poderia ter feito tal obra em nosso País, porque há mais de quarenta anos as pessoas de bem clamavam por providências dessa profundidade, sem que ela fosse concretizada. Eram as repartições que Ministros do Supremo Tribunal chamaram de "nódoas", "universidades do crime", "fábrica de bandidos"? Foi a Revolução de 31 de Março que acabou com isso, elevando o tratamento do menor ao nível de problema do campo psicossocial, que merece estudos da Escola Superior de Guerra e dos excelentes cursos das Associações de Diplomados da Escola Superior de Guerra. Proclamava-se que, nessa área, o Brasil inteiro caminha certo. Em qualquer
} 
Estado se encontra uma mentalidade diferente. Uma Revolução pode não derramar sangue, mas tem de derramar ideias, tem de mudar rotinas, quebrar mentalidades retrógradas que impedem o progresso e não permitem que o desenvolvimento social se estabeleça. E isso a Revolução fez e está fazendo em diversos setores, inclusive no campo do menor (1977, apud Becher, 2011, p. 11).

No plano discursivo, diante das críticas ao SAM, a criação de uma nova institucionalidade parecia ser a solução para a situação denunciada anteriormente. Contudo, não foi o que aconteceu, segundo os registros históricos, jurídicos e relatos sobre o período. De fato, a institucionalidade criada pela Funabem parece ter aprofundado as mazelas do modelo de intervenção anterior, definitivamente não se tratando de uma ruptura nesse caso, mas de uma marcada continuidade (Cifali, 2019).

Becher (2011) explica que a disciplina dentro das instituições juvenis foi militarizada e que, a partir de então, as instituições da justiça juvenil cerraram definitivamente suas portas para a sociedade, já que, como referido, anteriormente atuavam em conjunto com associações filantrópicas e de caridade. Valores relacionados com a preservação da família, o trabalho e o saneamento moral eram apontados como fundamentais para a manutenção de uma sociedade desenvolvida. Nesse momento, para o discurso oficial, a principal responsável pela situação da clientela preferencial daquele sistema de justiça seria a sua própria família, cabendo ao Estado assumir um papel tutelar (Barcellos e Fonseca, 2009).

Migliari (1993), Earp (1993) e Becher (2011) apontam para a utilização de argumentos baseados no trinômio "pátria, fé e família" para explicar a atuação estatal sobre os jovens em situação de vulnerabilidade nesse momento. Ao passo que as famílias eram culpabilizadas pela situação dos jovens, os objetivos da intervenção estatal em relação a essa parcela da população eram colocados em termos messiânicos e salvacionistas, como forma de proteger a nação e de moldar as crianças como cidadãos do futuro. "Missão", "redenção", “cruzada” e "salvação” da criança brasileira são conceitos que reaparecem com frequência nos discursos oficiais. Percebe-se que aqui, ainda, havia uma representação social da juventude que a identificava com o futuro da nação e com uma esperança. Nada muito distinto do discurso assistencialista e salvacionista anterior, agora em termos um pouco distintos, com o tom grandioso e moralista do discurso autoritário conservador promovido pelo governo militar.

A institucionalização era a medida central da intervenção dirigida aos jovens - fosse internar para tratar ou internar para prevenir -, que assumia um caráter repressivo de contenção e exclusão social daquilo que se pode chamar de clientela preferencial do sistema de justiça juvenil. Ao identificar o jovem em situação de vulnerabilidade como possível transgressor ou "criminoso em potencial", a institucionalização era a 
medida considerada necessária para evitar que o jovem cumprisse a previsão de seu destino, marcado pelo preconceito e pelo estigma (Migliari, 1993).

Segundo depoimentos de técnicos que atuaram nas Febems, em muitas instituições as crianças e adolescentes eram chamados por números, ao invés de seus próprios nomes. Diante de características como a vida rotinizada e a ênfase na higiene e na disciplina, as Febems foram alvo de críticas, especialmente no que dizia respeito aos maus-tratos perpetrados contra os adolescentes lá institucionalizados (Earp, 1993).

\section{A cPI do menor abandonado e novas tentativas de reforma}

Diante das denúncias relacionadas com as violências cometidas dentro das Febems, bem como diante da proeminência que o discurso de defesa de Direitos Humanos ganhava, impulsionado pelas normativas internacionais ${ }^{4}$, já era defendida uma alteração legislativa do Código de Menores e das práticas de atendimento à população infantojuvenil nos anos 1970. E, ao final da década, um amplo movimento começou a organizar-se com a finalidade de garantir os direitos das crianças e adolescentes no Brasil, ao denunciar a perversidade do aprisionamento de jovens em instituições estatais, as práticas discriminatórias com relação aos “meninos de rua”, os altos índices de violência contra os jovens em situação de vulnerabilidade e, especialmente, a ação de grupos de extermínio para eliminar essa parcela da população (Sudbrack, 2004). Havia, por parte daqueles que trabalhavam com jovens, a necessidade de tornar públicas as situações de violência e de negligência que presenciavam dentro e fora das instituições estatais (Cifali, 2019).

O problema conhecido como do "menor abandonado" volta a ser alvo de crescente atenção. No mesmo período, também começavam a despontar estudos sociais críticos que verificavam os efeitos perversos da institucionalização, bem como que desvelavam a situação de crianças e adolescentes em situação de rua. $\mathrm{O}$ tema, antes caracterizado pela escassez de dados e ausência de pesquisas que dimensionassem a questão desta infância em situação de vulnerabilidade, tornara-se um objeto de estudo cada vez mais abordado. De acordo com Rizzini e Rizzini (1996), houve uma vasta produção acadêmica na passagem dos anos 1970 para os anos 1980, reafirmando a importância que o tema adquiriu, verificando-se um aumento superior a 300\% na produção na década de 1980 em relação ao período entre 1975 e 1979, segundo informam.

\footnotetext{
4. No cenário internacional, à mesma época, muitos movimentos estavam colocando as crianças e os adolescentes no centro das discussões. Nesse sentido, destaca-se a publicação da Declaração dos Direitos da Criança, em 1959 (oNU, 1959), e o fato de 1970 ter-se tornado o ano internacional da criança no seio das Nações Unidas (ONU, 1970; Chies-Santos, 2018).
} 
Diante da relevância que o tema ganhava nas discussões públicas, entre junho de 1975 e abril de 1976, foi instaurada uma Comissão Parlamentar de Inquérito (CPI) "destinada a investigar o problema da criança e do menor carentes do Brasil", a qual passou a ser denominada "CPI do Menor Abandonado" ou "CPI do Menor". A CPI era apontada como um laboratório de pesquisas e de busca por soluções para "um doloroso amontoado de problemas que chocam e deprimem a consciência nacional" (Brasil, 1976, p. 3).

O objetivo da CPI era analisar as causas e os efeitos da marginalização social, entendendo os chamados "menores" enquanto vítimas, "em face da extrema vulnerabilidade características das famílias de baixos níveis de renda e das camadas mais pobres da população" (Brasil, 1976, p. 3). Indicava-se que o "menor" seria uma consequência da marginalização e que a "realidade brasileira do menor" assumia "proporções de calamidade social” (Brasil, 1976, p. 3).

Um dos objetivos dos movimentos sociais que se constituíram naquele momento era alterar o estado das coisas no campo, justamente para romper com a concepção da categoria "menor", que fora construída legal e institucionalmente desde o início do século Xx e que se consolidara como a maneira de se referir a uma juventude específica, notadamente crianças e adolescentes das camadas populares da população.

A chamada "marginalização do menor" era descrita como um fenômeno resultado das mudanças ocorridas na sociedade brasileira, o que acabava por gerar um "choque de valores", conflitos advindos do enfraquecimento dos laços sociais, em que as famílias eram as mais prejudicadas diante de problemas como o "crescimento demográfico acelerado, êxodo rural, deficiências médico-sanitárias, analfabetismo, desqualificação de mão de obra e pobreza" (Brasil, 1976, p. 4). Assim, o "problema do menor" permanecia como responsabilidade da família, influenciada pelo meio em que estava inserida e pelas profundas transformações sociais que atingiam a sociedade brasileira. A "marginalização do menor", ainda, era retratada como um processo social que apresentaria diversos níveis, destacando-se que "inicia-se como menor em via de marginalização social e culmina com o menor infrator, considerando-se a criminalidade o grau máximo da marginalização social” (Brasil, 1976, p. 4). Ainda conforme relatório da CPI, a miséria seria a "origem de todos os males e a causa mediata ou imediata da delinquência infantojuvenil” (Brasil, 1976, p. 7).

O relatório final da CPI citava a Declaração dos Direitos da Criança, promulgada pela ONU em 1959, incorporando o entendimento de que o "menor", por tratar-se de pessoa em desenvolvimento, "requer cuidados e atenções especiais no atendimento de suas necessidades" (Brasil, 1976, p. 5). Destacava-se, naquele período, que as Nações Unidas ressaltavam a importância do atendimento da criança como "recurso humano indispensável ao desenvolvimento nacional” e, também, citava-se o Unicef: 
"não se pode esperar uma mudança radical no panorama latino-americano, a menos que se iniciem políticas e planos que tenham como objetivo atender às necessidades da infância e juventude" (Brasil, 1976, p. 5).

A importância da instauração de uma CPI nesse momento é evidente. Em 1989, em meio aos debates parlamentares para a edição do Estatuto da Criança e do Adolescente, Nelson Aguiar - deputado, ator-chave no processo de aprovação do Estatuto - relembrou essa CPI, ao observar:

\begin{abstract}
Há exatamente 14 anos, houve a CPI do Menor, que constatou e quantificou a trágica realidade de sofrimento, abandono e denegação de direitos da maioria das nossas crianças e dos jovens de então. As conclusões dessa Comissão apontavam para a necessidade de mudanças estruturais profundas no sistema de atendimento, o que demandava uma ampla reformulação legal, se a Nação quisesse enfrentar adequadamente esse que era já considerado o maior dos desafios ao seu desenvolvimento (Aguiar, 1989a, p. 10794).
\end{abstract}

Segundo Marco Antônio da Silva - coordenador geral e conselheiro do Movimento Nacional Meninos e Meninas de Rua em São Bernardo do Campo e Guarulhos, em São Paulo -, o principal impacto da CPI foi o aumento da pressão para mudanças na legislação e o desenvolvimento de novos instrumentos para enfrentar a situação das crianças e adolescentes das camadas populares, assim como a violência contra elas (Castelfranchi, 2005).

\title{
O Código de 1979 e a ampliação do dispositivo da menoridade
}

Esse processo, que girou em torno do dispositivo disciplinar da menoridade, contribuiu para que, em outubro de 1979, um novo Código de Menores fosse aprovado, tendo sido elaborado, a pedido do Senado, por um grupo de juízes e juristas, contando também com a participação de um médico em sua formulação 5 .

Segundo Cavallieri, juiz de menores que participou desse processo, o novo texto “dividia os menores em dois grupos: menores com grave carência de atendimento em

5. O projeto era conhecido como "Substitutivo Paulista", devido à influência de juízes paulistas na elaboração do texto. O projeto era chamado de "substitutivo", pois, meses antes, um projeto de lei sobre o tema havia sido desarquivado e, no Congresso Nacional, foram recebidas inúmeras sugestões para complementar o texto, advindas de Universidades, Tribunais e entidades ligadas ao direito e aos movimentos pelos direitos das crianças. Porém, os parlamentares entenderam que deveriam partir de um projeto novo, tendo convocado os magistrados para elaborarem um novo texto, desconsiderando as sugestões recebidas (Ferreira e Noronha, 1993; Cifali, 2019). 
suas necessidades básicas, em razão da ausência ou omissão de pais ou responsável; e menores autores de infração penal” (1986, p. 39). De acordo com Ferreira e Noronha (1993), alguns juristas ainda requeriam a inclusão de ações a serem exercidas no âmbito social, político e econômico para minimizar as dificuldades pelas quais passavam os jovens em situação de vulnerabilidade, mas o Código aprovado não se ocupou de tais preocupações, recebendo críticas de que, ignorando os resultados da CPI, o novo Código de Menores representaria apenas a reforma cosmética da legislação anterior, vinculando-se seu processo de redação, sem a participação social, à ditadura militar.

O período marcado pelo regime militar, contexto em que o Código de Menores de 1979 foi criado, pode ser considerado um marco na utilização dos saberes "psi" ${ }^{6}$ no interior das estratégias de intervenção sobre a infância e a juventude em situação de vulnerabilidade - sem romper muitos dos parâmetros desenhados pelos ensinamentos da assim chamada Criminologia positivista, conforme exposto.

Para Cavallieri (1986, p. 41), a maior alteração introduzida pelos juízes de menores no anteprojeto de Código de Menores de 1979, já com a reformulação dos juristas paulistas, foi, "inegavelmente, aquela que implantou a chamada doutrina da situação irregular. A partir daí, fixou-se a destinação do Código e lastreou-se o fundamento do Direito do Menor". Essa era a principal característica da posição defendida pelos "juristas menoristas", a necessidade de elaboração de um campo do conhecimento específico, especializado. Os "menoristas" defendiam que o "problema” da intervenção estatal estava no âmbito da execução das determinações judiciais, e não na lei (Cifali, 2019).

Defendiam, na linha do que era propagado a partir da Funabem, uma visão dita "científica", em que eram unidas as ciências jurídicas e as "psi". Nos trechos da obra de Cavallieri (1986, p. 147) pode-se verificar que o chamado direito do menor era considerado "um conjunto de normas jurídicas dirigidas à definição (diagnóstico), tratamento (terapia) e prevenção (profilaxia) da situação irregular (estado de patologia social) do menor [...]”. Ainda, segundo o autor:

O historiador do futuro dividirá a proteção do menor no Brasil em duas épocas, antes e depois da Funabem. Esquecendo-se do equivocado período em que uma indicação política interrompeu a científica e adequada direção da Funabem começada por Mario Altenfelder. [...] Além de resultar na extinção do SAM, que se deteriorara apesar dos esforços de seus

6. Embora já marcasse presença anteriormente, nesse momento é possível perceber uma maior utilização dos recursos discursivos dos saberes "psi” e, especialmente, um maior uso de avaliações sobre a periculosidade dos jovens alvos preferenciais do sistema de justiça, em uma evidente continuidade do que já se constituía uma prática recorrente no âmbito do SAM, como apontado anteriormente (Cifali, 2019). 
dirigentes e funcionários, devido à sua colocação burocrática no Ministério da Justiça, a Funabem permitiu a elaboração de uma filosofia em que a ciência foi inserida no contexto de sua operatividade (Idem, p. 151).

Em 1979, a ONU elegeu aquele ano como o Ano Internacional da Criança, com o objetivo de sensibilizar o mundo para os problemas que afetavam a infância. O Fundo das Nações Unidas para a Infância (Unicef) ampliou sua atuação no Brasil - que já existia desde meados da década de 1950. É nesse período, também, que surgem experiências pastorais e populares importantes dentro da Igreja Católica, em defesa das crianças: o Movimento República do Pequeno Vendedor, na década de 1970, a Pastoral do Menor, em 1977, e o Movimento de Defesa do Menor em São Paulo, constituído por políticos e profissionais liberais (advogados, jornalistas, assistentes sociais, psicólogos). Paula (2011) relata a influência das pastorais e da Igreja Católica na formulação e execução do atendimento em meio aberto de crianças e adolescentes, que executavam seus trabalhos entre a filantropia e a política.

A reforma de 1979 continuava sendo destinada aos jovens considerados em situação de vulnerabilidade, agora oficializada no artigo $2^{\circ}$ da lei como "situação irregular", abarcando tanto aqueles considerados infratores como aqueles em situação de vulnerabilidade econômica e social ${ }^{7}$. Em definitivo, as condições pessoais, familiares e sociais continuavam determinando a situação da criança ou do adolescente, em mais uma reafirmação da prática de uma cultura jurídica e institucional que já atendia às disposições daquele Código de Menores de 1927. Conforme destacado por Saraiva (2005), o "novo" Código de Menores incluía em sua clientela praticamente 70\% da população infantojuvenil brasileira. O autor ainda aponta que $80 \%$ dos jovens privados de liberdade não haviam cometido qualquer infração (Idem). Ou seja, situações atípicas, em que adultos dificilmente seriam condenados, para crianças e adolescentes resultavam em privação de liberdade. De acordo com Earp (1993), ainda que o Código previsse medidas em meio aberto, como a liberdade assistida, a internação foi a medida historicamente escolhida pelos juízes brasileiros para encaminhar a assistência e a repressão da juventude em situação de vulnerabilidade no Brasil.

7. Consideravam-se em situação irregular as crianças e adolescentes: (1) privados de condições essenciais à sua subsistência, saúde e instrução em razão de falta, ação ou omissão dos pais ou responsáveis ou da manifesta impossibilidade dos pais ou responsável para provê-las; (2) vítimas de maus-tratos ou castigos imoderados impostos pelos pais ou responsáveis; (3) em perigo moral, devido a encontrar-se, de modo habitual, em ambiente contrário aos bons costumes e em exploração de atividade contrária aos bons costumes; (4) órfãos ou em situação de abandono; (5) vistos com desvio de conduta, em virtude de grave inadaptação familiar ou comunitária; e, por fim, (6) os apontados como autores de infração penal (Brasil, 1979). 
Os juízes seguiram imbuídos de amplos poderes na tomada de decisões sobre a vida de crianças e adolescentes, especialmente a partir da perspectiva de que o magistrado não deveria ocupar-se apenas das questões tipicamente jurídicas, mas também deveria ser capaz de suprir as deficiências impostas pela ausência de políticas públicas adequadas (Cifali, 2019).

Nesse sentido, destaca-se o conceito de completude institucional que acompanhava tal modelo de intervenção, em que as instituições como a Febem deveriam dar conta de "toda a problemática do menor", conforme o texto da lei. Na prática, isso significava que a instituição era responsável por todas as áreas da vida do jovem, como saúde, educação e assistência. Todo o atendimento era centralizado e realizado dentro da instituição, sem qualquer tipo de relação com outros setores ou políticas públicas. Esse conceito de "completude institucional" autorizava a retirada de jovens do convívio social para que suas demandas fossem, supostamente, atendidas dentro da instituição (Cifali, 2019).

Para Earp (1993), embora consideradas instituições educacionais e profissionalizantes, não se encontrava qualquer dimensão efetivamente educativa nas práticas institucionais do período, enredando o jovem num emaranhado burocrático cruel, o qual nunca era efetivamente observado em sua dignidade. A rígida disciplina institucional, ao menos em sua moldura geral, permanecia reproduzindo os mecanismos de exclusão social.

Ressalta-se que, malgrado a demanda dos movimentos dos profissionais críticos não tenha sido levada em consideração na redação da legislação, ela continuou se fortalecendo. Com a intensificação do discurso baseado nos Direitos Humanos e com estudos sociais críticos no período de transição democrática, bem como a partir das diretrizes internacionais emanadas por organismos como a ONU e a OEA, foi importante, nesse contexto, a consolidação da percepção “desenvolvimentista”. Tal concepção entendia que crianças e adolescentes mereceriam atendimento especializado em razão de sua condição especial de pessoa em desenvolvimento, perspectiva adotada pelo Brasil e pelos principais organismos internacionais de Direitos Humanos ${ }^{8}$, os quais recomendavam - e seguem recomendando - a existência de um sistema de justiça especializado para processar, julgar e responsabilizar jovens autores de delitos?.

8. Especialmente a partir de 1985, com as Regras Mínimas das Nações Unidas para a Administração da Justiça da Infância e da Juventude (ONU, 1985), são traçadas as principais características de um modelo de justiça juvenil baseado nos direitos humanos e considerado adequado pela comunidade internacional, tendo sido adotado por diversos países, entre eles, o Brasil.

9. O Brasil é signatário de diversos instrumentos de proteção que indicam o proceder estatal nesse sentido, como as Regras Mínimas das Nações Unidas para a Administração da Justiça, da Infância e da Juventude, conhecidas como Regras de Beijing (ONU, 1985), da Convenção Internacional sobre os Direitos da Criança (onu, 1989), as Diretrizes das Nações Unidas para a Prevenção da Delinquência Juvenil - 
Por fim, destaca-se uma perspectiva de longa duração que coloca em evidência um sentido de progressividade da política e da institucionalidade menorista ao longo do século $\mathrm{xx}$, alinhado às práticas sociais já estabelecidas em torno do dispositivo disciplinar menorista, que só vão ser alvo de rupturas, ainda que parciais, no final do século, como veremos adiante (Roige, 2010).

\section{Abertura democrática e as críticas ao modelo de intervenção estatal}

A ruptura, ao menos em termos legislativos, em relação ao tratamento menorista dispensado a crianças e adolescentes só ocorreu com a abertura democrática no Brasil. A Constituição da República de 1988 e a criação do Estatuto da Criança e do Adolescente (ECA), em 1990, recepcionaram a Doutrina da Proteção Integral, momento em que as crianças e os adolescentes passaram a ser considerados cidadãos com direitos plenos, mas, em razão de sua condição peculiar de desenvolvimento, sujeitos à proteção especial ${ }^{10}$.

Aliado a isso, com a proliferação de estudos sobre o tema, passou-se a ter acesso a um conjunto de informações que não estavam anteriormente sistematizadas. Essas informações repercutiam na sociedade, ao traduzir em números "uma problemática cujas evidências não se podiam mais subestimar" (Rizzini e Rizzini, 1996, p. 70). As estratégias de sobrevivência da "criança pobre" eram o tema de diversas pesquisas e estudos de campo que tinham como objetivo corrigir e ampliar o conhecimento existente sobre as condições de vida de crianças e adolescentes em situação de vulnerabilidade econômica e social.

De menores abandonados que necessitavam de caridade ou da intervenção assistencial do Estado, reconhecia-se que havia milhões de crianças atingidas pelas mazelas da pobreza e pelas deficiências das políticas públicas básicas. Rizzini e Rizzini (1996) destacam que essa compreensão possibilitou uma mudança radical

Diretrizes de Riad (ONU, 1990). A Convenção Internacional sobre os Direitos da Criança - ratificada internamente pelo Decreto 99.710/90 - estabelece que criança é o sujeito de até dezoito anos de idade. Conforme tal convenção e, também, de acordo com as Regras de Beijing e as Diretrizes de Riad, existe uma divisão entre a fase adulta e a fase infantojuvenil, bem como tais documentos distinguem os tratamentos estatais perante as práticas delituosas.

10. Vale ressaltar que foi a partir da introdução do artigo 227 na Constituição brasileira que efetivamente se começou a romper, em termos legais, com a legislação menorista vigente até então. Durante a redemocratização do Brasil, no final da década de 1980, houve a reafirmação do papel de protagonismo dos movimentos sociais e o fortalecimento da sociedade civil, elementos que se relacionavam intimamente com o processo geral de abertura democrática e com a busca pela modificação das instituições do país (Pilotti e Rizzini, 1993). Assim, ganharam força os movimentos pela garantia de direitos das crianças e dos adolescentes, os quais entendiam que a mudança legislativa era fundamental para romper com o dispositivo menorista. 
de perspectiva e abriu espaço para o surgimento de novas propostas de intervenção sobre essa realidade. Houve uma conscientização crescente, por parte da sociedade, em relação à situação dessa parcela da população juvenil, que passou a ser percebida como parte de uma conjuntura política marcada pela desigualdade social. De acordo com Rizzini e Rizzini (1996, p. 87):

É preciso que se diga com todas as letras, e temos base científica para o fazer, que, ao contrário do que convenientemente se manteve por muito tempo, essas crianças não são órfãs, abandonadas ou perigosas. São, antes, vítimas de um sistema injusto, que lhes nega o básico e as condena ao descaso, ao abandono e à orfandade de sua cidadania.

Ainda, os problemas de pesquisa diziam respeito às características comuns às crianças privadas de liberdade, aos motivos para sua internação, aos efeitos da internação e às representações sociais sobre os jovens privados de liberdade (Cifali, 2019). Além disso, buscavam traçar o "perfil" do jovem institucionalizado, geralmente chegando à conclusão de que eram, em sua maioria, negros e advindos de áreas periféricas das grandes cidades (Rizzini e Rizzini, 1996).

Até então eram escassas as pesquisas que trabalhavam com a intersecção entre juventude e criminalidade. Sobre a ausência de estudos sobre a prática de delitos por jovens, Rizzini e Rizzini (1996, pp. 83-86) apontavam que isso constituía uma enorme lacuna, e que pouco se sabia sobre a vinculação de jovens com a criminalidade. Desobediência, perambulância, furto, roubo, vadiagem, fuga de casa e consumo de drogas eram termos que apareciam como causas que frequentemente levavam os jovens às instituiçôes privativas de liberdade. Sobre os efeitos da internação, percebia-se que as instituições se situavam em locais distantes das comunidades de origem dos jovens, levando ao enfraquecimento de vínculos familiares e comunitários. Passa-se a articular a crítica de que a internação causa mais danos do que benefícios. Aduzia-se que, principalmente por longos períodos, a internação seria prejudicial em vários aspectos, em especial no processo de formação da identidade, na escolarização e no desenvolvimento das relações sociais (Cifali, 2019).

A questão da constituição da identidade da criança e do adolescente privado de liberdade passa a ser alvo de preocupação, especialmente por parte de autores com formação em psicologia, surgindo trabalhos alinhados com a teoria do etiquetamento (labelling approach), perspectiva que concentra sua atenção sobre os aspectos que definem a conduta humana, substituindo o paradigma da escola positivista - aquele etiológico - pelo do controle social. É nesse momento que os estudos vão deslocar o foco: das causas da criminalidade para os processos de criminalização (Cifali, 2019). 
Além disso, obras como as de Erving Goffman (1961) e Michel Foucault (1977), ao problematizarem os aspectos estigmatizadores e disciplinadores das instituições sociais, passam a ter maior presença nos debates, diante do impacto de sua produção na academia brasileira. Nesse sentido, em 1984, Queiroz abordava a saída do menor da instituição, ao mostrar que a marca da Febem e da polícia daria a certeza de que ele seria intrinsecamente criminoso, sendo estigmatizado diante da sociedade, tendo em vista que a Funabem era retratada como uma "fábrica de marginais" (Queiroz, 1984).

No mesmo ano, Campos (1984) abordou a mesma questão, ao analisar que a instituição imporia ao jovem uma identidade idealizada de "recuperado", mas tratando-o de acordo com a identidade atribuída de "infrator". O autor também destacava o preconceito da sociedade para com os chamados "menores" que, depois da institucionalização, enfrentariam problemas para se inserirem novamente na sociedade e que o jovem acabaria por cumprir a carreira que a instituição lhe traçava, ao adquirir a identidade que lhe era atribuída e distanciando-se cada vez mais do modelo de identidade dos considerados “normais". Para Altoé (1990), a internação era baseada no silêncio, na submissão e no atendimento violento, não havendo lugar para diferenciação, elemento que dificultaria a formação de indivíduos autônomos. Ainda, tais autores mostraram que as representações que os jovens teriam de si mesmos seriam influenciadas pela imagem negativa e preconceituosa que a instituição e a sociedade têm deles.

Tais pesquisas críticas ${ }^{11}$ ajudaram a provocar uma acirrada discussão sobre os efeitos da institucionalização na trajetória de vida dos jovens, contribuindo para a fundamentação das denúncias que se seguiram contra uma prática caracterizada como discriminatória, violenta e estigmatizante, bem como para a formulação de alternativas de atendimento a essa população, menos repressivas.

Assim, na década de 1980, os estudos sociais tiveram um papel fundamental no processo de desenvolvimento de um novo olhar crítico em relação ao modelo de intervenção estatal sobre a juventude em situação de vulnerabilidade que vinha sendo operado. Defendia-se uma abordagem social e educativa junto aos "meninos e meninas de rua" por meio da prática e da perspectiva oferecidas por alternativas comunitárias de atendimento, entendidas como "um caminho promissor" (Costa et al., 1996, p. 10). Assim, nesse momento de críticas à institucionalização, passou a ser defendido um atendimento realizado no âmbito comunitário.

11. Trabalhos como o realizado pelo Centro Brasileiro de Análise e Planejamento, intitulado A criança,o adolescente, a cidade (Cebrap, 1972), Meninos de rua (Ferreira, 1979), pesquisa encomendada ao Centro de Estudos de Cultura Contemporânea (Cedec), pela Comissão de Justiça e Paz de São Paulo, e $O$ dilema do decente malandro (Violante, 1982), entre outros, também foram importantes no período. 
Essa percepção da necessidade de implementação de práticas comunitárias levou um grupo de técnicos do Unicef, da Funabem e da Secretaria de Ação Social (sAs) vinculada ao Ministério da Previdência e Assistência Social (MPAS) - a darem início ao Projeto de Alternativas de Atendimento a Meninos de Rua, com base em um termo de acordo técnico-financeiro celebrado entre dirigentes das três instituições. A Flacso integrou-se ao processo mediante convênios com o MPAS, iniciando com a SAS a avaliação e o acompanhamento de diversos programas, com o objetivo de localizar e identificar as organizações e programas não institucionalizantes e comunitários, baseados na educação social de rua, iniciativas divergentes da política então em vigor (Costa et al., 1996).

$\mathrm{O}$ evento que marcou esse momento foi o I Seminário Latino-Americano de Alternativas Comunitárias de Atendimento a Meninos e Meninas de Rua, realizado em Brasília no mês de novembro de 1984. "Ali, o atendimento alternativo revelou-se perante a Nação com toda sua força e com todo seu frescor de planta nova emergindo com vigor na rica e diversificada floração do movimento social brasileiro naquele período" (Costa et al., 1996, p. 10). A partir de tal evento, as alternativas comunitárias de atendimento impuseram-se com uma crítica ao modelo assistencialista e disciplinar-repressivo ${ }^{12}$. O Movimento Nacional de Meninos e Meninas de Rua (MNMMR) é um dos protagonistas nesse momento. Composto majoritariamente por profissionais que trabalhavam na atenção direta à população de crianças e de adolescentes em situação de rua, reunia profissionais que passaram a questionar as práticas direcionadas à população por eles atendida.

O caráter de disputa e resistência ante o modelo de intervenção a ser adotado começa a ganhar força no cenário nacional e fica explícito neste trecho do MNMMR:

Ao fortalecer as práticas alternativas que visam à mudança do trabalho institucional com os menores, cavamos brechas para justamente influenciar uma nova postura de trabalho. Às vezes, é uma posição de confronto que se torna inevitável nesta nossa proposta. Por exemplo, pode tornar-se difícil dialogar com a Febem e esta dificuldade não é a de falar com o presidente da

12. Esse movimento em torno de alternativas comunitárias de atendimento faz recordar o trabalho de Cohen (1988), em que descreve a tendência observada nos anos de 1960, no Canadá, por uma revisão dos métodos de intervenção estatal que tinham como foco reduzir a institucionalização e ampliar a intervenção no âmbito comunitário. O autor destaca movimentos como a antipsiquiatria e os movimentos destinados a modificar ou abolir centros de privação de liberdade. Nesse contexto, toma força um discurso em defesa da reforma do sistema penal e das alternativas à prisão, em que os profissionais que trabalhavam nas instituições do sistema penal tiveram um papel central para que as antigas práticas fossem questionadas. Porém, segundo o autor, mais do que uma redução da intervenção estatal, uma consequência desse movimento foi a expansão da intervenção estatal para o meio aberto - o que também pode ser observado no Brasil com a edição do ECA. 
entidade, mas porque a prática da instituição em si mesma já é uma violência, com contenção e repressão, e nada mais (MNMMR, 1988).

O movimento buscava uma articulação com outros setores da sociedade, ao afirmar que a questão dos jovens "menores" não era isolada de outras questões sociais, o que inclusive pode ser identificado à intersetorialidade que depois viria a ser adotada pelo ECA, em oposição à completude institucional pautada pela PNBEM (MNMMR, 1988; Cifali, 2019).

Uma das ações mais relevantes nesse período foi a realização do I Encontro Nacional de Meninos e Meninas de Rua, em 1986, em Brasília. Esse evento colocou em evidência a natureza política e a identidade do MNMMR. Nos níveis local e estadual de debates, crianças e adolescentes participavam das discussões, de modo que sua apropriação sobre o tema surpreendeu parlamentares e observadores.

Em 1985, ainda nesse contexto de discussões sobre novas formas de intervenção e atendimento da juventude, foi realizado em São Paulo o Encontro Nacional "Paulo Freire e os Educadores Sociais", destacando-se a produção teórica do autor que embasava as reflexões sobre os meninos e meninas de rua, a educação social e os educadores sociais de rua. Em obra publicada em 1989 pelo Unicef, Paulo Freire e educadores de rua: uma abordagem critica. Alternativas de atendimento aos meninos de rua, a apresentação é assinada pelo Projeto Alternativas de Atendimento a Meninos de Rua Unicef/sas/Funabem, salientando que, diante das importantes reflexões e debates realizados na oportunidade do evento, a coordenação do Projeto decidiu organizar a publicação (Unicef, 1989) ${ }^{13}$.

13. A introdução da obra revela que desde 1983 o Unicef havia iniciado uma série de ações de apoio a governos, igrejas, instituições privadas e comunidades no sentido de defesa de jovens em situação de vulnerabilidade social na América Latina. Assim, verifica-se que tais ações, desenvolvidas e apoiadas no Brasil pelo Unicef, faziam parte de uma ampla ação realizada na América Latina, a partir do Programa Regional do Menino Abandonado e de Rua, com a finalidade de chamar atenção para as situações de violência e negligência enfrentadas por essa população (Unicef, 1989). De acordo com a publicação, um dos objetivos do Programa Regional do Menino Abandonado e de Rua era "favorecer a difusão de informação e a divulgação de modelos de atenção não convencionais" (Idem, p. 8). Lembrando que "convencional", na época, era o modelo de institucionalização. Assim, o escritório regional tinha a responsabilidade de compilar experiências inovadoras nesse campo, além de produzir e distribuir materiais escritos e audiovisuais referentes a metodologias e modelos de atenção a jovens em situação de risco social. Dentre os princípios propostos pelo Unicef (1989), os quais se buscava difundir, estavam a contrariedade à "institucionalização do menor" e a ampliação da participação da comunidade nos modelos de intervenção estatal. Dentro de tal modelo, tinha atenção especial a figura do educador de rua, aquele que forneceria a atenção ao jovem sem retirá-lo de seu ambiente comunitário, buscando fortalecer os vínculos familiares e comunitários, elemento que, anos depois, viria a integrar o ECA. Vale destacar que, em tal obra, também é possível perceber uma leitura da situação dos meninos e meninas de rua que identifica um sistema social responsável por sua situação de vulnerabilidade (Unicef, 1989). 
Nesse contexto, Brasil, México, Colômbia e Equador são destacados pelo órgão da ONU como sendo pioneiros nos esforços para colocar em prática projetos experimentais de atenção aos jovens em situação de rua. Assim, a organização exerceu um papel importante como propulsora de movimentos da sociedade civil pela infância e adolescência na região, tendo realizado um amplo trabalho de promoção de formas alternativas de intervenção e defesa dos direitos humanos das crianças e adolescentes junto aos governos e instituições privadas, além de fornecer apoio técnico e financeiro para impulsionar as mudanças legais do período (Unicef, 1989).

Havia o entendimento de que a convocação de uma Assembleia Nacional Constituinte configurava um momento e uma oportunidade únicos para "colocar o nascente Estado Democrático de Direito para funcionar em favor das crianças e adolescentes" (Costa et al., 1996, p. 11).

Assim, a Comissão Nacional Criança e Constituinte realizou um amplo processo de sensibilização, conscientização e mobilização da opinião pública e dos constituintes. Foram realizados Encontros Nacionais, debates em diversos Estados, ampla difusão de mensagens nos meios de comunicação, eventos envolvendo centenas de crianças em frente ao Congresso Nacional, distribuição de panfletos e abordagem pessoal aos parlamentares, participação dos membros da Comissão em Audiências Públicas dos grupos de trabalho responsáveis pelas diversas áreas temáticas do texto constitucional, bem como foi elaborada uma carta de reivindicações contendo mais de 1,4 milhões de assinaturas de crianças e adolescentes, exigindo dos parlamentares a introdução de seus direitos na nova Constituição Federal (BRASIL, 2018b).

A partir, então, da instalação da Assembleia Nacional Constituinte, em 1987, um grupo de trabalho foi designado para sintetizar, em forma de dispositivo legal, os direitos fundamentais de crianças e adolescentes, momento em que é elaborado o artigo 227 da Constituição Federal de 1988, o qual determina como dever da família, da sociedade e do Estado assegurar-lhes os direitos à vida, à saúde, à alimentação, à educação, ao lazer, à profissionalização, à cultura, à dignidade, ao respeito, à liberdade e à convivência familiar e comunitária, além de colocá-los a salvo de toda forma de negligência, discriminação, exploração, violência, crueldade e opressão. Consolida-se, assim, a Doutrina da Proteção Integral, em oposição à Doutrina da Situação Irregular, manifestada nos antigos Códigos de Menores (de 1927 e 1979).

O artigo 227 da Constituição da República é considerado a base normativa para a elaboração do Estatuto da Criança e do Adolescente (ECA), pois os integrantes dos movimentos pelos direitos das crianças e adolescentes, bem como aqueles que atuavam no sistema de Justiça juvenil, entendiam que o antigo Código de Menores não era compatível com a nova situação legal consolidada em âmbito constitucional. 
Isso significa que o Código de Menores tinha se tornado inconstitucional nesse momento de abertura democrática, marcado pela promulgação da Constituição de 1988.

Assim, houve uma ampla articulação e mobilização nacional para a construção daquilo que viria a se tornar o ECA, em 1990 (Oliveira, 2005). Diversos grupos articularam-se no Fórum Nacional de Entidades Não Governamentais de Defesa das Crianças e dos Adolescentes para exercerem pressão no Congresso Nacional para a aprovação da nova legislação.

\section{O Estatuto da Criança e do Adolescente}

A construção do ECA contou com a participação de técnicos contratados pelo Unicef, com o apoio de magistrados, de membros do Ministério Público, de políticos e de lideranças pertencentes a instituições governamentais. Foram realizadas diversas audiências públicas, em diferentes localidades do país, para discussão do texto legal, as quais contavam, inclusive, com a participação de crianças e adolescentes atendidos pelos projetos comunitários.

Ressalta-se que os debates eram permeados por disputas entre aqueles que defendiam o modelo menorista e aqueles que pleiteavam sua alteração. Porém, ambos os setores eram favoráveis à manutenção de uma justiça especializada voltada ao público infantojuvenil. A principal diferença entre os dois grupos era a visão que tinham em relação à natureza da intervenção estatal sobre a vida dos jovens. Enquanto os "menoristas" percebiam a intervenção estatal e, inclusive, a privação de liberdade como um bem, capaz de produzir resultados positivos no sentido de modificação de condutas e trajetórias, os "garantistas" entendiam que as intervenções estatais trariam sempre um conteúdo negativo, de violações de direitos (Cifali, 2019; Chies-Santos, 2018).

De acordo com o ECA, os adolescentes são sujeitos de direitos e a eles estão assegurados todos os deveres e direitos resguardados aos adultos, em consonância com a Constituição da República de 1988. Isso quebraria, em tese, com a lógica menorista que vigorava até então. Passou-se, desse modo, da Doutrina da Situação Irregular à Doutrina da Proteção Integral, em concordância com as normativas internacionais.

Dessa forma, o ECA parte da compreensão de que as normas jurídicas que tratam de crianças e adolescentes devem concebê-los como cidadãos plenos, sujeitos à proteção prioritária (art. 227 da Constituição da República), superando o paradigma da incapacidade, substituído pela óptica desenvolvimentista da condição peculiar de pessoa em desenvolvimento físico, psicológico e moral. Além disso, a legislação volta-se à infância e à adolescência sem qualquer tipo de discriminação por critérios econômicos ou sociais (Ferreira, 2017). 
A legislação cria, igualmente, um sistema de garantias e proteção para as crianças e adolescentes, em que situações de vulnerabilidade não são criminalizadas: em situações em que o adolescente se encontra com seu direito ameaçado ou violado, não é ele que se encontra em situação irregular, e sim as instituições responsáveis. Reconhecem-se, também, todas as garantias que são concedidas a adultos nos processos criminais, além de mais algumas garantias específicas, nos casos que envolvem a prática de atos infracionais. Os adolescentes devem ser julgados por tribunais específicos, com direito a defesa e reconhecendo-se que, por serem pessoas em desenvolvimento, a sua responsabilização é diferente da do adulto. E, por tal motivo, devem-se priorizar, sempre que possível, as medidas socioeducativas em meio aberto e considerar a medida socioeducativa de internação uma excepcionalidade, sempre sujeita ao princípio de brevidade.

Os princípios pedagógicos que regeriam as medidas socioeducativas, como a excepcionalidade e a brevidade da medida de internação, possibilitariam o fortalecimento de vínculos familiares e comunitários. A internação era pensada apenas para casos especiais, tidos como de maior gravidade. De fato, a descentralização das políticas de atendimento à infância e à juventude foi uma das maiores inovações do ECA, momento em que o Estado passa a compartilhar com a comunidade e com a família a responsabilidade pela efetivação dos direitos infantojuvenis, assim como o controle sobre essa parcela da população, conforme preconiza a própria Constituição.

A partir do ECA, foram elaboradas disposições distintas para adolescentes envolvidos com a prática de atos infracionais e aqueles em situação de abandono ou vulnerabilidade. A legislação incorporou as garantias constitucionais e do processo penal, determinando a proteção de direitos individuais, entre eles a ampla defesa, o devido processo legal e o contraditório nos processos envolvendo atos infracionais. Nesse novo contexto, a figura do juiz de menores é afastada, impondo-se ao Judiciário seu papel de julgador técnico com poderes limitados pelas garantias processuais, com a finalidade de limitar intervenções abusivas por parte do Estado (Saraiva, 2005). A rotina disciplinadora das instituições totalizantes cede um pouco de espaço para a análise e avaliação do âmbito individual de cada adolescente, por meio de um Plano Individual de Atendimento (PIA). Ao lado de regras rígidas que determinam o cotidiano nas instituições socioeducativas, colocam-se as metas a serem alcançadas individualmente por cada adolescente. Ou seja, se antes o Estado intervinha na crença de que uma rotina disciplinar poderia transformar o adolescente através do hábito, a partir do ECA um novo programa correcional é anunciado, com foco na identidade, mas sem deixar de lado a disciplina anterior (Raniere, 2014).

De acordo com Méndez (2006), mais do que substituir as antigas práticas repressivas, o ECA veio se opor às práticas tutelares, ao partir da constatação de que 
os abusos cometidos contra os jovens em situação de vulnerabilidade se davam em nome de uma suposta compaixão paternalista. Assim, Méndez aponta o ECA como uma mudança de paradigmas, lendo as novas diretrizes introduzidas pela legislação como "uma verdadeira revolução cultural" (Méndez, 2000, pp. 7-24; Cifali, 2019).

No cotidiano da justiça juvenil, ainda que tenha havido avanços com relação às práticas anteriores - a redução dos castigos físicos legitimados institucionalmente, por exemplo -, é possível observar a recorrente violação e a relativização das garantias trazidas pelo ECA. Passetti, por exemplo, aponta que o ECA não fugiria da lógica jurídica que identifica a infração com o crime e a medida socioeducativa com a pena, ao destacar a moralidade conservadora, a desconfiança com relação às medidas não privativas de liberdade e a morosidade do judiciário como elementos que acabariam gerando um grande número de internações (Passetti, 1995).

Saraiva (2005), por sua vez, sublinha que o ECA traria em seu bojo algumas concessões à velha doutrina menorista, as quais acabariam por obstaculizar sua eficácia, haja vista o caráter genérico de muitas de suas disposições, que abririam espaço para a discricionariedade e o arbítrio. Na própria legislação, indica-se que o ato infracional não é o ponto central a ser considerado no julgamento, abrindo espaço para avaliações sobre o contexto social, econômico e familiar dos jovens, remontando à velha Doutrina da Situação Irregular.

Nesse sentido, diversos trabalhos apontam críticas ao ECA e à sua aplicação, tendo em vista que os direitos dos adolescentes continuam sendo violados, desde sua abordagem pela polícia até à execução de medidas em meio aberto e fechado. Gisi (2015) ressalta o tempo indeterminado como forma de controle social dentro das unidades de internação. Cornelius (2018) trata da imposição de medidas socioeducativas antes do trânsito em julgado da sentença condenatória, assinalando a violação da presunção de inocência. Goldani (2014) avalia a influência do contexto familiar nas decisões judiciais a respeito de atos infracionais, identificando que o intervencionismo familiar ainda se faz presente. Além disso, Lugon (2014), Foscarini (2014), Lazzarotto e Carvalho (2014) apontam para a medicalização excessiva de adolescentes em unidades de internação, destacando que a patologização de condutas segue justificando a privação de liberdade de adolescentes. Ainda, em pesquisa para a série "Pensando o Direito" (Brasil, 2010) constatou-se que:

[...] os dados coletados junto aos Tribunais de Justiça e Superior Tribunal de Justiça em matéria de medida socioeducativa de internação e, posteriormente, a observação de casos junto às Varas da Infância e Juventude de São Paulo, Porto Alegre, Recife e Salvador permitiram concluir que, apesar das propostas garantidoras do Estatuto, a prática forense nem sempre está com elas alinhada. Foi possível constatar que a medida de internação é sistematicamente 
imposta com baixa fundamentação legal. Em muitos casos, sem a devida consideração dos requisitos legais exigidos pelo ECA.

Assim, apesar de o ECA representar, ao menos no plano do formalismo jurídico, certa ruptura com os ditames anteriores, é possível perceber, ainda no plano normativo, a permanência de elementos característicos da legislação menorista, como a indeterminação do tempo de privação de liberdade, ainda que agora limitado a três anos, e a ampla discricionariedade conferida aos magistrados. Tem-se, assim, uma nova legislação que, em alguns pontos, mantém os postulados menoristas e, em outros, busca formas de rompê-los, sendo um resultado das disputas travadas entre as diferentes formas de compreender a intervenção estatal direcionada a essa parcela da população ${ }^{14}$.

\section{Considerações finais: entre permanências e rupturas}

Logo após a aprovação do ECA, houve aqueles que já atentaram para a necessidade de efetiva superação do anterior paradigma da situação irregular. Adorno, por exemplo, já avaliava que: "A efetiva superação desse passado policialesco e repressivo dependerá da capacidade do complexo institucional existente de incorporar transformações e mostrar-se sensível ao atendimento em meio aberto" (Adorno, 1993, pp. 101-112). O autor indicava sua preocupação com relação à mudança de mentalidade que deveria ser promovida para que se tomassem efetivamente os jovens como sujeitos de direitos (Idem). Tal preocupação não era infundada, tendo em vista as dificuldades em se transformarem práticas e racionalidades construídas há muito tempo. Além disso, em grande medida, o ECA não foi capaz de suprimir a ampla discricionariedade conferida aos magistrados, limitando-se a impor alguns limites básicos referentes ao processo penal de um Estado Democrático de Direito, como a ampla defesa e o contraditório ${ }^{15}$.

Estudos recentes têm apontado para a permanência de resquícios da doutrina da situação irregular nas práticas contemporâneas da justiça juvenil no Brasil (Almeida, 2015, 2016; Cifali, 2019; Vinuto, 2019; Chies-Santos, 2018; Cornelius, 2018). Pode-se indagar, em direção um pouco diversa, se um efetivo dispositivo histórico de governo de crianças e de adolescentes emerge no país, desde meados do século XX, ao reproduzir, em períodos históricos bastante diversos, em termos políticos e institucionais, formas de rotulação e de estigmatização baseadas em atributos raciais, de

14. A esse respeito, ver Cornelius (2018).

15. Ressalta-se, contudo, que tais princípios não são garantidos na fase pré-processual, notadamente na oitiva informal, momento em que é facultada a presença de defesa. Isso pode gerar graves consequências ao adolescente, já que estará frente à autoridade ministerial e não terá nenhuma defesa (Brasil, 1990). 
gênero e de classe. Ao articular práticas dos agentes repressivos, formas de classificação presentes na vida social, doutrinas e leis, bem como diversos saberes especializados, a reprodução complexa de tal dispositivo permanece como enigma a ser decifrado por pesquisas de âmbitos disciplinares diversos. Nesta reflexão, buscou-se caracterizar, mesmo que seletivamente, aspectos da trajetória da Justiça Juvenil no país a partir de olhares críticos da Criminologia, da Sociologia e de áreas vizinhas, tendo como pano de fundo o questionamento acerca das continuidades e das rupturas aí presentes.

Do Código de Menores de 1927 ao ECA, disputas entre os mais diversos atores e saberes desenharam discursos, leis e instituições que não lograram integrar efetivamente crianças e jovens, sobretudo negros e pobres, ao horizonte da cidadania no país. Talvez caiba à crítica reiterar a insuficiência das saídas colocadas e não necessariamente desenhar novas leis e instituições, ao expandir, deste modo, as possibilidades da reflexão para o desenho de novas políticas na área.

Mesmo a condição de sujeitos de direitos inaugurada pelo ECA não conseguiu atingir a todos os adolescentes de forma igualitária, como era almejado no momento de sua aprovação. A desconstrução efetiva do dispositivo da menoridade provavelmente demandará, para além das alterações normativas, profundas mudanças no âmbito da cultura institucional e de outras dimensões correlacionadas, capazes de romper com as práticas e lógicas fundadas no preconceito e no estigma que permitem a continuidade da seletividade de parcela específica da população infantojuvenil brasileira como alvos preferenciais do que se denomina justiça juvenil no Brasil.

\section{Referências bibliográficas}

Adorno, Sérgio. (1993), “Criança: a lei e a cidadania”. In: Rizzini, Irene (org.). A criança no Brasil hoje: desafios para o terceiro milênio. Rio de Janeiro, Editora Universitária Santa Úrsula, pp. 101-112.

Aguiar, Nelson. (29 set. 1989a), Diário do Congresso Nacional, Brasília/DF, ano XLIV, n. 127, pp. 10794. Discurso proferido na Câmara dos Deputados. Disponível em http://imagem. camara.gov.br/Imagem/d/pdf/DCD29sET 1989.pdf\#page=128, consultado em 12/10/2017.

Almeida, Bruna Gisi de. (2015), "O tempo indeterminado como instrumento de manutenção da ordem interna em unidades de internação para adolescentes”. $39^{\circ}$ Encontro Anual da Anpocs, Caxambu.

Almeida, Bruna Gisi de. (2016), A racionalidade prática do isolamento institucional: um estudo da execução da medida socioeducativa de internação em São Paulo. São Paulo, tese de doutorado, Programa de Pós-Graduação em Sociologia da Universidade de São Paulo. Altoé, Sônia. (1990), Infâncias perdidas: o cotidiano nos internatos-prisão. Rio de Janeiro, Xenon. Alvarez, Marcos César. (1989), A emergência do Código de Menores de 1927: uma análise do 
discurso jurídico e institucional de assistência e proteção aos menores. São Paulo, dissertação de mestrado, Faculdade de Filosofia, Letras e Ciências Humanas da Universidade de São Paulo.

Alvarez, Marcos César. (2002), “A criminologia no Brasil ou Como tratar desigualmente os desiguais". Dados: Revista de Ciências Sociais, Universidade do Rio de Janeiro, Rio de Janeiro, 45 (4): 77-704.

Alvarez, Marcos César. (2003), Bacharéis, criminologistas e juristas: saber jurídico e Nova Escola Penal no Brasil. São Paulo, IBCCRim.

Alvarez, Marcos César. (jan./mar. 2004), "Controle social: notas em torno de uma noção polêmica”. São Paulo em Perspectiva, 18: 168-176.

Alvarez, M. C. \& Salla, Fernando. (maio 2000), "Paulo Egídio e a Sociologia Criminal em São Paulo”. Tempo Social, 12 (1): 101-122.

Alvarez, M. C.; Salla, F. (2018), “Os novos contornos do bacharelismo liberal: uma análise da trajetória de Cândido Motta (1870-1942)”. Politica \& Sociedade, 17 (39): 86-120.

Amado, Jorge. ([1937] 2014), Capitães da areia. Posfácio de Milton Hatoum. São Paulo, Companhia das Letras.

Barcellos, Daisy Macedo \& Fonseca, Claudia. (2009), “Um sobrevoo de pesquisas sobre instituições para adolescentes em conflito com a lei”. In: FonsECA, Claudia \& SCHUCH, Patrice (orgs.). Políticas de proteção à infância. Um olhar antropológico. Porto Alegre, UfrGs, pp. 197-218.

Barreto, Tobias. (1926), Menores e loucos e fundamento do direito de punir. Rio de Janeiro, Empreza Graphica Editora de Paulo Pongetti \& C. Obras completas, v. v, Direito.

BECHER, Franciele. (jul. 2011), “Os 'menores’ e a Funabem: influências da ditadura civil-militar brasileira”. Anais do XXVI Simpósio Nacional de História - ANPUH, São Paulo.

Braga, Ana Beatriz. (1993), A construção social da infância trabalhadora na Primeira República. Rio de Janeiro, dissertação de mestrado em Sociologia, Instituto de Filosofia e Ciências Sociais da Universidade Federal do Rio de Janeiro.

Brasil. Senado Federal, Secretaria de Informação Legislativa. (1923), "Decreto n. 16.272”. Disponível em legis.senado.gov.br/legislacao/ListaNormas.action?numero=16272\&tipo_ norma $=$ DEC \&data $=19231220 \&$ link $=$, consultado em 10/01/2017.

Brasil. Presidência da República, Casa Civil. (12 out. 1927), “Decreto n. 17.943-a”. Disponível em www.planalto.gov.br/ccivil_03/decreto/1910-1929/d17943a.htm, consultado em 5/1/2017.

Brasil. Presidência da República, Casa Civil. (7 dez. 1940), "Decreto-Lei 2.848. Código Penal”. Disponível em: www.planalto.gov.br/ccivil_03/decreto-lei/Del2848.htm, consultado em $9 / 3 / 2017$.

Brasil. Presidência da República, Casa Civil. (22 maio 1968), “Lei n. 5.439”. Disponível em: www.planalto.gov.br/ccivil_03/leis/1950-1969/L5439impressao.htm, consultado em $10 / 1 / 2017$. 
Brasil. Diário do Congresso Nacional. Ano XXXI - suplemento ao n. 65. (10 jun. 1976), "Projeto de Resolução n. 81. Da CPI do menor". Disponível em: http://imagem.camara. gov.br/Imagem/d/pdf/DCD10Jun1976sup.pdf, consultado em 07/04/2018.

Brasil. Ministério da Justiça. Secretaria de Assuntos Legislativos. (2010), ECA: Apuração do ato infracional atribuido a adolescentes. Série Pensando o Direito, n. 26/2010. Brasília, Universidade Federal da Bahia (UfBA), Coordenação Maria Auxiliadora Minahim.

CAmpos, Ângela Valadares Dutra de Souza. (1984), O menor institucionalizado, um desafio para a sociedade: atitudes, aspirações eproblemas para sua reintegração na sociedade. Petrópolis, Vozes.

Castelfranchi, Yurij. (2005), "Estatuto da Criança e do Adolescente: um marco na luta pelos direitos". In: Vogt, Carlos (ed.). Geografia do país da infância. Infância. Reportagens. Disponível em https://www.comciencia.br/dossies-1-72/reportagens/2005/12/02.shtml.

Cavallieri, Alyrio. (1986), Direito do menor. Rio de Janeiro, Forense.

Cebrap - Centro Brasileiro de Análise e Planejamento. (1972), A criança, o adolescente, a cidade. São Paulo.

Chies-Santos, Mariana. (2018), Resistentes, conformados e oscilantes: um estudo acerca das resistências produzidas pelos adolescentes privados de liberdade no Brasil e na França. Porto Alegre, tese de doutorado em Sociologia, Universidade Federal do Rio Grande do Sul.

Cifali, Ana Claudia. (2019), As disputas pela definição da justiça juvenil no Brasil. Porto Alegre, tese de doutorado em Ciências Criminais, Pontifícia Universidade Católica do Rio Grande do Sul.

Cohen, Stanley. (1988), Visiones de control social: delitos, castigos y clasificaciones. Tradução de Elena Larrauri. Barcelona, PPU.

Cornelius, Eduardo Gutierrez. (2018), O pior dos dois mundos? A construção legítima da punição de adolescentes no Superior Tribunal de Justiça. São Paulo, IBCCRIM.

Costa, Antônio Carlos Gomes; Kayayan, Agop \& Fausto, Ayrton. (1996), "Prefácio. Do avesso ao direito: de menor a cidadão". In: Fausto, Ayrton \& Cervini, Rubem (orgs.). O trabalho e a rua: crianças e adolescentes no Brasil urbano dos anos 80. São Paulo, Cortez, Unicef, Flacso-Brasil, pp. 9-14.

Donzelot, Jacques. (1980), A polícia das famílias. Rio de Janeiro, Graal.

EARp, Maria de Lourdes Sá. (1993), “A política de atendimento do século Xx: a infância pobre sob tutela do Estado". In: BAzílıo, Luiz Cavalieri; EArP, Maria de Lourdes \& NoronHA, Patrícia Anido (orgs.). Infância tutelada e educação: história, política e legislação. Rio de Janeiro, Ravil, pp. 72-100.

Faleiros, Vicente de Paula. (2009), “Infância e processo político no Brasil”. In: Rizzini, Irene \& Pilotti, Francisco (orgs.). A arte de governar crianças: a história das politicas sociais, da legislação e da assistência à infância no Brasil. Rio de Janeiro, Editora Cortez.

Fausto, Boris. (1984), Crime e cotidiano: a criminalidade em São Paulo (1880-1924). São Paulo, Brasiliense. 293p. 
Ferreira, Carolina Costa. (2017), A politica criminal no processo legislativo. Belo Horizonte, D’Plácido.

Ferreira, Mônica Silva \& Noronha, Patrícia Anido. (1993), "Legislações que tutelaram a infância e a juventude no Brasil”. In: BAZílio, Luiz Cavalieri; EARP, Maria de Lourdes \& Noronha, Patrícia Anido (orgs.). Infância tutelada e educação: história, política elegislação. Rio de Janeiro, Ravil, pp. 135-160.

Ferreira, Rosa Maria Fischer. (1979), Meninos de rua. São Paulo, Comissão de Justiça e Paz/ Cedec. 173p.

FosCARINI, Leia Tatiana. (2014), “Quando as violações ocorrem em nome da proteção: apontamentos sobre o uso abusivo de medicação nas unidades de internação de adolescentes da fase/rs". In: Costa, Ana Paula Motta \& Eilberg, Daniela (orgs.). Justiça Juvenil na Contemporaneidade. Porto Alegre, Ufrgs, pp. 113-119.

Foucault, Michel. (1977), Vigiar e punir: o nascimento da prisão. Petrópolis, Vozes.

Foucault, Michel. (1980), História da sexualidade I: a vontade de saber. 3 ed. Rio de Janeiro, Graal.

Goffman, Erving. ([1961] 2003), Manicômios, prisões e conventos. Tradução de Dante Moreira Leite. São Paulo, Perspectivas.

Goldani, Júlia Maia. (2014), “A influência do contexto familiar nas decisões judiciais a respeito de atos infracionais de adolescentes: o intervencionismo penal ainda se faz presente?". In: Costa, Ana Paula Motta \& EILBERg, Daniela (orgs.). Justiça juvenil na contemporaneidade. Porto Alegre, UfRgs, pp. 220-242.

Gonçalves, Vitor Sousa. (2020), “O sistema de justiça juvenil na perspectiva sociológica: Entre frouxa articulação e linha de montagem”. Dilemas, RJ, 13 (3): 781-799.

Lazzarotto, Gislei Domingas \& Carvalho, Julia Dutra de. (2014), "Adolescente em medida socioeducativa: tensões entre políticas de saúde mental e a patologização-medicalização”. In: Costa, Ana Paula Motta \& EILberg, Daniela (orgs.).Justiça juvenil na contemporaneidade. Porto Alegre, UfRgs, pp. 120-129.

Lombroso, Cesare. (1887), L’homme criminel. Paris, Félix Alcan.

Lugon, Ricardo. (2014), “Patologização da internação socioeducativa: a medicalização”. In: Costa, Ana Paula Motta \& EIlberg, Daniela (orgs.).Justiça juvenil na contemporaneidade. Porto Alegre, UfRgs, pp. 108-112.

MÉndez, Emílio Garcia. (2000), Adolescentes e responsabilidade penal: um debate latino americano. Porto Alegre, Ajuris.

Migliari, Maria de Fatima Bastos Menezes. (1993), Infância e adolescência pobres no Brasil: análise social da ideologia. Rio de Janeiro, dissertação de mestrado em Sociologia e Política, Pontifícia Universidade Católica do Rio de Janeiro, PUCRJ.

Mineiro, Beatriz Sofia. (1929), Código dos menores dos Estados Unidos do Brasil commentado. São Paulo, Companhia Editora Nacional. 
Oliveira, Maria Cristina Cardoso Moreira de. (2005), Processo infracional e violência. Porto Alegre, dissertação de mestrado em Ciências Criminais, Pontifícia Universidade Católica do Rio Grande do Sul, PUCRS.

Onu, Organização das Nações Unidas. (29 nov. 1985), Regras Minimas das Nações Unidas para a Administração da Justiça da Infância e da Juventude (Regras de Beijing).

Onu, Organização das Nações Unidas. (20 nov. 1989), Convenção Internacional dos Direitos da Criança.

Onu, Organização das Nações Unidas. (14 dez. 1990), Princípios Orientadores das Nações Unidas para a Prevenção da Delinquência Juvenil (Princípios Orientadores de Riade).

Passetti, Edson. (1991), “O menor no Brasil República”. In: Del Priore, Mary (org.). História da Criança no Brasil. São Paulo, Contexto.

Passetti, Edson et al. (1995), Violentados: crianças, adolescentes e justiça. São Paulo, Imaginário. Paula, Liana de. (2011), Liberdade assistida: punição e cidadania na cidade de São Paulo. São Paulo, tese de doutorado em Sociologia, Faculdade de Filosofia, Letras e Ciências Humanas da Universidade de São Paulo, Usp.

Pilotti, Francisco \& Rizzini, Irene. (1993), “A (des)integração na América Latina e seus reflexos sobre a infância”. In: Rızzini, Irene (org.). A criança no Brasil hoje: desafios para o terceiro milênio. Rio de Janeiro, Editora Universitária Santa Úrsula, pp. 41-65.

Platt, Antony M. (1982), Los “salvadores del niño” o la invención de la delincuencia. México, Siglo Veintiuno.

Queiroz, José J. (org.). (1984), O mundo do menor infrator. São Paulo, Cortez/Autores Associados.

Raniere, Édio. (2014), A invenção das medidas socioeducativas. Porto Alegre, tese de doutorado em psicologia social e institucional, Instituto de Psicologia da Universidade Federal do Rio Grande do Sul, UfRGS.

Rizzini, Irene. (1993), “O elogio do científico: a construção do 'menor' na prática jurídica”. In: Rizzıni, Irene (org.). A criança no Brasil hoje: desafios para o terceiro milênio. Rio de Janeiro, Editora Universitária Santa Úrsula, pp. 81-101.

Rizzini, Irene \& Rizzini, Irma. (1996), “'Menores' institucionalizados e meninos de rua: os grandes temas de pesquisas na década de 80". In: Fausto, Ayrton \& Cervini, Rubem (orgs.). O trabalho e a rua: crianças e adolescentes no Brasil urbano dos anos 80. São Paulo, Cortez, Unicef, Flacso-Brasil, pp. 69-90.

Roige, Mariana. (2010), Niñez, marginalidad y politicas públicas. Análisis de un dispositivo estatal. Buenos Aires, Libros de la Araucaria.

SALLÉE, Nicolas. (2016), Éduquer sous contrainte: une sociologie de la justice des mineurs. Paris, Éditions de L'Ehess.

Saraiva, João B. Costa. (2005), Adolescente em conflito com a lei. Da indiferença à proteção integral. Uma abordagem sobre a responsabilidade penal juvenil. Porto Alegre, Livraria do Advogado. 
Sudbrack, Umberto Guaspari. (2004), “O extermínio de meninos de rua no Brasil”. São Paulo Perspec. [online], 18 (1):22-30. Disponível em http://www.scielo.br/scielo.php?script=sci_ arttext\&pid=S0102-88392004000100004\&lng=pt\&nrm=iso, consultado em 15/10/2020.

Unicef. (1989), Paulo Freire e educadores de rua: uma abordagem critica. Alternativas de atendimento aos meninos de rua. Série Metodológica. Programa Regional Menores em cirunstancias especialmente difíciles, n. 1. Colômbia.

UniCEF. Unicef Brasil. Biblioteca. (2015), \#ECA25anos: Fazemosparte dessa história. Disponível em https://www.unicef.org/brazil/pt/resources_30430.html, consultado em 15/8/2018.

Vianna, Adriana de Resende B. (1999), O mal que se advinha: polícia e menoridade no Rio de Janeiro, 1910-1920. Rio de Janeiro, Arquivo Nacional.

Vinuto, Juliana. (2019), O outro lado da moeda: O trabalho de agentes socioeducativos no estado do Rio de Janeiro. Rio de Janeiro, tese de doutorado no Programa de Pós-graduação em Antropologia e Sociologia da Universidade Federal do Rio de Janeiro.

Violante, Maria Lúcia Vieira. (1982), O dilema do decente malandro. São Paulo, Cortez.

\section{Resumo}

Justiça juvenil no Brasil: continuidades e rupturas

O presente ensaio tem por objetivo retomar a discussão acerca da trajetória da justiça juvenil no Brasil. A partir do diálogo com trabalhos já realizados no âmbito da Sociologia, da Criminologia e áreas vizinhas, pretende-se refletir acerca das possíveis continuidades e rupturas, ao longo da história brasileira, dessa justiça no país. Dos Códigos de Menores de 1927 e 1979 ao ECA, passando pela criação do Serviço de Assistência aos Menores, da Funabem etc., operadores do direito, setores das elites políticas, especialistas e pesquisadores, movimentos sociais, imprensa e outros atores redesenharam permanentemente essa área de atuação estatal, ao mobilizar saberes e diagnósticos diversos. Busca-se recuperar a complexidade de tal trajetória histórica para melhor refletir acerca dos paradoxos da justiça juvenil ainda na atualidade.

Palavras-chave: Justiça juvenil; Dispositivo da menoridade; Adolescentes em conflito com a lei; Estatuto da Criança e do Adolescente.

\section{Abstract}

Juvenile justice in Brazil: continuities and ruptures

This essay aims to resume the discussion about the trajectory of juvenile justice in Brazil. Based on the dialogue with works already carried out in the scope of Sociology, Criminology and other areas, it is intended to reflect on the possible continuities and ruptures, throughout Brazilian history, of this justice. From the Codes of Minors of 1927 and 1979 to ECA, including the creation of the Assistance Service for Minors, Funabem etc., legal operators, sectors of political elites, specialists and researchers, social movements, the press and other actors have permanently redesigned this area, by mobilizing diverse knowledge and diagnoses. It seeks to recover the 
complexity of such a historical trajectory in order to better reflect on the paradoxes of juvenile justice even today.

Keywords: Juvenile Justice; Minority Device; Court-Involved Youth; Estatuto da Criança e do Adolescente.

Texto recebido em 19/10/2020 e aprovado em 31/10/2020.

DOI: 10.11606/0103-2070.ts.2020.176331.

Ana Claudia Cifali é doutora (2019) e mestra em ciências criminais pela pucrs (2015). Mestra em cultura de paz, conflitos, educação e direitos humanos pela Universidade de Granada (2012). Advogada do programa Prioridade Absoluta do Instituto Alana. E-mail: ana.cifali@ alana.org.br.

Mariana Chies-Santos é advogada e socióloga. Doutora em sociologia pela Ufrgs (2018) e mestra em ciências criminais pela PUCRS (2012). Atualmente é pesquisadora com bolsa de pós-doutorado no Núcleo de Estudos da Violência da USP (NEV-USP) e coordenadora-chefe do Departamento de Infância e Juventude do IBCCRIM. E-mail: chiesmariana@usp.br.

Marcos CÉsar Alvarez é sociólogo, professor livre-docente no Departamento de Sociologia da USP. Possui graduação em ciências sociais (1984), mestrado (1989) e doutorado (1996) em sociologia, todos obtidos na Universidade de São Paulo, e pós-doutorado na École des Hautes Études en Sciences Sociales, Paris (2008-2009). Coordenador do Núcleo de Estudos da Violência da Universidade de São Paulo (NEv-UsP) e pesquisador bolsista de Produtividade em Pesquisa do CNPq.E-mail: mcalvarez@usp.br. 